\title{
Response of Chickpea (Cicier Arietinium L.) to Rhizobium Inoculation and Blended fertilizer Rates in Laelay Maichew, Central Zone of Tigray, Northern Ethiopia
}

\author{
Kiros Wolday ${ }^{1} \&$ Atsede Teklu ${ }^{1}$ \\ ${ }^{1}$ Crop core process Axum Agricultural Research Center, Tigray Agricultural Research Institute, Ethiopia \\ Correspondance: Kiros Wolday, Crop core process, Axum Agricultural Research Center, Tigray Agricultural \\ Research Institute, Ethiopia. Tel: 251-925-425-358. E-mail: kiroswolday@gmail.com
}

Received: June 15, 2020 Accepted: July 17, 2020 Published: August 11, 2020

\begin{abstract}
Low soil fertility is one of the limiting factor for low productivity of chickpea in Central zone of Tigray, Northern Ethiopia. Field experiment was therefore, conducted for two consecutive years (2016-2017) in Laelay Maichew (Hatsebo) to evaluate the effects of NPSB fertilizer and rhizobium inoculation on yield and yield components of chickpea. The experiment was laid out in a split plot design with three replications. Rhizobium inoculation was assigned to the main plots with two levels (with and without rhizobium inoculation) and NPSB fertilizer rates in sub plot with seven levels $\left(0,25,50,75,100,125\right.$ and $\left.150 \mathrm{~kg} \mathrm{ha}^{-1} \mathrm{NPSB}\right)$. Data collected were subjected to the analysis of variance (ANOVA) using SAS software. A combined analysis of variance showed a significant interaction effects of NPSB and rhizobium inoculation on chickpea yield and yield components $(\mathrm{P}<0.05)$ across the two years. The highest number of pods per plant (76.8) was recorded from $125 \mathrm{~kg} \mathrm{ha}^{-1}$ NPSB along with rhizobium inoculation and the highest grain yields were obtained from $150 \mathrm{~kg} \mathrm{ha}^{-1}\left(3609 \mathrm{~kg} \mathrm{ha}^{-1}\right)$ and $125 \mathrm{~kg} \mathrm{ha}^{-1}$ NPSB (3514 kg ha-1) along with rhizobium inoculation. Maximum marginal rate of return (4106.68\%) was gained when chickpea was inoculated with rhizobium and $125 \mathrm{~kg} \mathrm{ha}^{-1}$ NPSB application. From the present results it could be concluded that $125 \mathrm{~kg} \mathrm{ha}^{-1}$ NPSB along with rhizobium inoculation seeds would be the optimum treatment combination for enhancing chickpea yield and better profitability in soils with low level of available plant nutrients (NPSB).
\end{abstract}

Keywords: Chickpea, marginal rate of return, NPSB, rhizobium inoculation, yield

\section{Introduction}

In Ethiopia pulses are among the various crops produced in all the regions of the country after cereals (CSA, 2018). In $2017 / 18$ pulses were cultivated in about $1.6 \times 10^{6}$ ha with annual estimated production of 2,978,588 tons (CSA, 2018). Among the pulses crops, chickpea is an important annual crop. It is only cultivated species of genus Cicer. Chickpea is the world's third most important food legume next to haricot bean and soybean (Namvar and Sharifi 2011). Globally it was cultivated on area of 13.65 million ha with production of 13.10 million tons (FAOSTAT, 2016). It is grown in 35 countries of the world. India, Turkey, Pakistan, Iran, Mexico, Myanmar, Ethiopia, Australia, Spain, Canada and USA are top ten chickpea producing countries. Ethiopia contributed around $3 \%$ of the global chickpea production. In Africa, Ethiopia is the leading chickpea producer and ranked third in its production next to faba bean and haricot bean (FAOSTAT, 2012).

Chickpea is a relatively cheap source of protein (20-23\% in the grain), energy (carbohydrates, 40\%), oil (3-6\%) (Gil etal.,1996) and minerals (Mg, K, P, Fe, Zn, and Mn (Ibrikci et al 2003) and $\beta$-carotene (Milan etal., 2006) in the developing world. Chickpea contributes significantly to sustainability of cereal-legume cropping systems, increasing the yield of cereals through enhancing the soil nitrogen and breaking the disease cycles of important cereal pathogens (Pande et al.,2011). However its productivity is low (1630 kg ha-1) in Tigray compared to the national average (2053 $\mathrm{kg} \mathrm{ha}^{-1}$ ) in Ethiopia (CSA, 2018) and very much below the potential of the crop.

Moisture stress (drought) mainly terminal drought, decline in soil fertility, diseases (dry root rot, wilt) insect pests (pod borer and cut worm) are the major constraints for low productivity of chickpea. Declining in soil fertility is one of the constraints contributing for low chickpea production and productivity. Many of the soils in Ethiopia are deficient in N, P, K, S (EthioSIS, 2014). Moreover, soil fertility declining is aggravetaed due to intensive cropping 
and unbalanced use of fertilizers by the farmers. Therefore, balanced fertilization is needed for optimum growth and production of crops including chickpea.

In the study area, use of fertilizer was focused mainly on the use of nitrogen (urea) and phosphorous (di-ammonium phosphate-DAP) for almost all crops. Such unbalanced application of plant nutrients might have aggravated the depletion of nutrient elements in soils including the recently identified S and micronutrient (B). Hence, the yield gap in pulses in general and chickpea in particular could be fulfilled through combined application of biofertilizers (rhizobium inoculants) and blended fertilizers along with improved varieties. There is also a need to consider the relative cost and profitability of these technologies with the respect to their adoption by small-holder farmers. This study was therefore initiated with to evaluate the sole and comined rhizobium and blended (NPSB) fertilizer application on yield and yield components chickpea. It was hypothesized that application of optimum NPSB fertilizer rates combined with rhizobium inoculation would improve yield and agronomic traits of chickpea in the study area.

\section{Materials and Methods}

\subsection{Description of The Study Site}

The experiment was conducted at Hatsebo experimental site of Axum Agricultural Research Center. The experimental site is located $5 \mathrm{~km}$ East from Axum town of Tigray regional state, Northern Ethiopia at $14^{\circ} 6^{\prime} 46^{\prime \prime} \mathrm{N}$ and $38^{\circ} 46^{\prime} 3^{\prime \prime} \mathrm{E}$ and attitude of 2084 meter above sea level. It has a Vertisols dominated clay soil type. It is situated in the northern semi-arid tropical belt of Ethiopia where teff, chickpea, wheat and faba bean are commonly grown. Chickpea is an important crop in the area both economically and ecologically. The rainy season is mono modal concentrated in one season from July to September and receives from 400 to $800 \mathrm{~mm}$ rainfall per annum.

\subsection{Experimental Design, Treatments and Procedures}

The experiment was carried out for two consecutive years (2016- 2017) during the rain fed conditions. The experiment was conducted in a split plot design with three replications at Axum Agricultural Research Station (Hatsebo site) and sown at mid August. The main factor was rhizobium inoculation with two levels (inoculated and uninoculated). The sub-plots factor was blended fertilizer rates with seven treatments $(0,25,50$, and $75,100,125,150 \mathrm{~kg}$ NPSB ha- ${ }^{-1}$. The experiment was conducted in a plot size of $3 \mathrm{~m}$ length by $2.4 \mathrm{~m}$ width with spacings of $0.10 \mathrm{~m}, 0.30 \mathrm{~m}, 0.50 \mathrm{~m}, 1 \mathrm{~m}$ and $1.5 \mathrm{~m}$ between plants, rows, sub plots, main plots and replications, respectively.

Popular and predominant grown improved chickpea variety (Arerti) was used for the trial. The recommended biofertilier level $500 \mathrm{~g} \mathrm{ha}^{-1}$ was used for chickpea inoculation. Rhizobium chickpea strain CP-M-41 was obtained from Menagesha Biotech industry P.L.C, Addis Ababa, Ethiopia. It is popular strain across the country in enhancing chickpea yield and yield components. The inoculants were prepared based on the recommended rate of $10 \mathrm{~g} \mathrm{~kg}^{-1}$ seeds for inoculation. Before planting, $1.5 \mathrm{~kg}$ of Chickpea (Arerti) seeds was prepared for inoculation. Seeds were soaked in water for 30 minutes. Then excess water was removed from the seeds by placing in a sack. There after sugar was applied as adhesive material to stick the inoculums in to the seeds. Finally the inoculants was applied to the seeds and dressed until the seeds showed a black color in a shade to avoid direct sun light so as to maintain the viability of the inoculums.

Blended fertilizer (NPSB) at rates of 0, 25, 50, 75,100,125,150 $\mathrm{kg} \mathrm{ha}^{-1}$ were applied at the center of the row and covered with soil to avoid contact with the inoculated seeds. At seed sowing, daily laborers were grouped into two before planting was started. One group planted the inoculated seed on the other hand the other group planted the non inoculated seeds. Finally, plots planted with inoculated seeds were immediately covered with soil to avoid direct sun light.

\subsection{Soil Sampling, Preparation and Analysis}

Pre-sowing surface soil samples were collected at 0-30 cm depth diagonally from 20 spots in the experimental field using an Auger. Sub samples were composited and processed for soil analysis before sowing. Composite soil samples were analyzed for organic carbon (OC), total N (Kjeldahl method) and available soil P (Olsen method). Particle size was determined following the hydrometer method. Cation exchange capacity, EC and soil pH were also measured using standard laboratory procedures followed by Shire Soil Research Center.

\subsection{Agronomic Data Collection}

Days to $90 \%$ maturity was recorded for all the plots when $90 \%$ of the plot was ready for harvesting when the foliage color becomes yellowish, lower pods starting shedding pods and seeds harden. At harvesting time, plant height and number of pods plant ${ }^{-1}$ were estimated from randomly tagged six plant samples in each plot. Harvesting 
was done from the central six rows Threshing was done manually after a week. Grain yield of the six inner 6 rows was measured by using sensitive balance and converted $\mathrm{kg} \mathrm{ha}^{-1}$. Grain yield of each plot was adjusted to $12 \%$ seed moisture content. Finally 100 seed data were weighed by counting 100 seeds from each plot by using sensitive balance.

\subsection{Statistical Analysis}

All collected data were subjected to the analysis of variance (ANOVA) using the SAS computer program, version 9.1 (SAS, 2002). Error variance of the individual years was tested for homogeneity. Treatment means were compared using least significant difference at $5 \%$ probability level (Petersen, 1994).

\subsection{Partial Budget Analysis}

Partial budget analysis of the rhizobium and blended (NPSZnB) fertilizer treatments were performed on the basis of prevailing market prices (CIMMYT,1988). The partial budget analysis was performed to assess treatment combinations that would give acceptable returns at low risk to farmers. All costs and benefits were calculated on hectare basis in Ethiopian birr (ETB). Variable costs (fertilizer and Rhizobium, Application and transport costs) were considered for partial budget analysis. Mean grain yield of the two years result were used for partial budget analysis. The average grain yield was adjusted to $10 \%$ downwards to reflect the difference between the experimental yield and the yield farmers will expect from the same treatment.

\section{Results and Discussion}

\subsection{Experimental Soil Selected Physical and Chemical Properties}

Selected soil physical and chemical properties of the experimental site before planting are indicated in Table 1 . The soil textural class is clay. The soil $\mathrm{pH}$ was neutral and non-saline (EthioSIS, 2014). The soil $\mathrm{pH}$ is in optimal $\mathrm{pH}$ range for most plants. Soil organic carbon and total nitrogen were low according to the rating of Tekalign et al. (1991). Available $\mathrm{P}$ was in the marginal level while cation exchange capacity was high according to the rating of Landon (1991).

Table 1. Physico-chemical properties of the experimental site soil before planting $(0-30 \mathrm{~cm})$

\begin{tabular}{cc}
\hline Soil characters & Values \\
\hline Clay (\%) & 66 \\
Sand (\%) & 12 \\
Silt (\%) & 22 \\
Textural class & Clay \\
Soil pH & 7.2 \\
OC (\%) & 0.67 \\
Total N (\%) & 0.06 \\
Available P (mg kg $\left.{ }^{-1}\right)$ & 10.28 \\
CEC (meq $100 \mathrm{~g} \mathrm{~g}^{-1}$ soil) & 58.4 \\
EC (dS m $\left.{ }^{-1}\right)$ & 0.986 \\
\hline
\end{tabular}

Notes: CEC: cation exchange capacity; EC: electrical conductivity; N: nitrogen; P: phosphorus; OC: organic

\subsection{Effects on Yield and Yield Components}

The interaction effects are presented and discussed as most of the parameters are significantly affected by the combination effects of rhizobium and NPSB application in chickpea (Tables 2, 3 and 4). Analysis of variance result showed that significant differences among the majority of yield and yield components of chickpea for the interaction effect of NPSB and rhizobium inoculation.

There was significant $(\mathrm{p}<0.05)$ interaction effects of rhizobium inoculation along with NPSB application on 90\% days to maturity in a separate year and combined over years. A significant and increasing trend was observed in $90 \%$ days to maturity with increasing among the rhizobium NPSB fertilizer levels. The shortest days to maturity (108.33) was recorded in the untreated check. On the contrary, the longest days to maturity (113) was observed in the maximum fertilizer doses and inoculation across the two years (Table 4). This could be attributed to the high nitrogen due to the increased $\mathrm{N}$-in the higher fertilizer rates and able to fix of atmospheric nitrogen due to rhizobium inoculation. Abdula (2013) reported that the delay in maturity recorded at the maximum fertilizer dose combined with rhizobium inoculation. 
Table 2. Effect of inoculation and NPSB application on Chickpea Yield and Yield Components in L/maichew (Hatsebo), 2016

\begin{tabular}{cccccc}
\hline Ino*NPSB $\left(\mathrm{kg} \mathrm{ha}^{-1}\right)$ & $90 \% \mathrm{DTM}$ & $\mathrm{PH}(\mathrm{cm})$ & NPPL & $\mathrm{GY}\left(\mathrm{kg} \mathrm{ha}^{-1}\right)$ & $\mathrm{HSW}(\mathrm{g})$ \\
\hline $0 * 0$ & $104 \mathrm{e}$ & $33.8 \mathrm{e}$ & $52 \mathrm{e}$ & $1625.7 \mathrm{f}$ & $25 \mathrm{e}$ \\
$0 * 25$ & $106 \mathrm{bcd}$ & $35.93 \mathrm{cde}$ & $55.2 \mathrm{de}$ & $1779.8 \mathrm{ef}$ & $25.5 \mathrm{de}$ \\
$0 * 50$ & $105.67 \mathrm{cde}$ & $36.53 \mathrm{cde}$ & $53.5 \mathrm{de}$ & $2075.8 \mathrm{de}$ & $25.13 \mathrm{e}$ \\
$0 * 75$ & $105 \mathrm{de}$ & $37.2 \mathrm{bcd}$ & $65.47 \mathrm{~b}-\mathrm{d}$ & $1821.3 \mathrm{ef}$ & $25.7 \mathrm{cde}$ \\
$0 * 100$ & $106.67 \mathrm{a}-\mathrm{d}$ & $36.97 \mathrm{bcd}$ & $73.33 \mathrm{a}-\mathrm{d}$ & $2653.8 \mathrm{c}$ & $26.87 \mathrm{ab}$ \\
$0 * 125$ & $106.33 \mathrm{bcd}$ & $38.27 \mathrm{abc}$ & $77.6 \mathrm{abc}$ & $2256.9 \mathrm{~cd}$ & $27.07 \mathrm{ab}$ \\
$0 * 150$ & $107.33 \mathrm{abc}$ & $37.87 \mathrm{~b}$ & $75.2 \mathrm{abc}$ & $2522.1 \mathrm{c}$ & $26.73 \mathrm{abc}$ \\
$1 * 0$ & $105 \mathrm{de}$ & $34.47 \mathrm{de}$ & $61.37 \mathrm{cde}$ & $1670.2 \mathrm{ef}$ & $25.8 \mathrm{cde}$ \\
$1 * 25$ & $105 \mathrm{de}$ & $36 \mathrm{cde}$ & $63.6 \mathrm{cde}$ & $2284.7 \mathrm{~cd}$ & $25.4 \mathrm{e}$ \\
$1 * 50$ & $105.33 \mathrm{de}$ & $37.07 \mathrm{~cd}$ & $69.4 \mathrm{~b}-\mathrm{e}$ & $2397.9 \mathrm{~cd}$ & $26.53 \mathrm{bcd}$ \\
$1 * 75$ & $106.67 \mathrm{a}-\mathrm{d}$ & $37.73 \mathrm{bc}$ & $75.6 \mathrm{abc}$ & $3349.8 \mathrm{~b}$ & $26.6 \mathrm{bc}$ \\
$1 * 100$ & $107.67 \mathrm{ab}$ & $38.73 \mathrm{abc}$ & $92.7 \mathrm{a}$ & $3210.9 \mathrm{~b}$ & $27.27 \mathrm{ab}$ \\
$1 * 125$ & $107.33 \mathrm{abc}$ & $39.07 \mathrm{ab}$ & $85.2 \mathrm{ab}$ & $3626.7 \mathrm{ab}$ & $27.37 \mathrm{ab}$ \\
$1 * 150$ & $108.33 \mathrm{a}$ & $40.99 \mathrm{a}$ & $78.6 \mathrm{abc}$ & $3785.1 \mathrm{a}$ & $27.67 \mathrm{a}$ \\
\hline Grand mean & 106.17 & 37.19 & 69.91 & 10.01 & 26.33 \\
LSD $(5 \%)$ & 1.67 & 2.93 & 19.98 & 419.3 & 1.04 \\
CV $(\%)$ & 0.94 & 4.7 & 17.09 & 10.01 & 2.96 \\
\hline
\end{tabular}

Ino indicates for Rhzobium inoculantion; $0=$ uninoculated, $1=$ inoculated with rhizobium; $\mathrm{DM}=$ days to maturity; $\mathrm{PH}=$ plant height; $\mathrm{NPPL}=$ number of pods per plant; $\mathrm{GY}=$ grain yield; $\mathrm{HSW}=$ hundred seed weight. Means followed by the same letter(s) with in a column are not significantly different at $\mathrm{P}=0.05$

With regard to the plant height the analysis of variance test showed a significant statistical difference $(\mathrm{P}<0.05)$ among the interaction effect of rhizobium inoculation and NPSB application in the single year as well as over years. The highest plant height $(40.40 \mathrm{~cm})$ was obtained from the interaction effect of rhizobium inoculation and NPSB application over the two years (Table 4) and the shortest plant height $(32 \mathrm{~cm})$ was recorded from the untreated check. This could be attributed to the high nitrogen source obtained from the fixed N- due to inoculation rhizobium inoculants as well as maximum vegetative growth of the plants under higher $\mathrm{N}$ availability from the higher NPSB levels.

Number of pods per plant significantly $(\mathrm{P} \leq 0.05)$ influenced by combine effect of rhizobium inoculation and NPSB levels in the separate years as well as across the two years (Tables 2,3 and 4). Significantly highest number of pods per plant was counted from the combine effect of rhizobium inoculation and $125 \mathrm{~kg}$ NPSB ha-1 (65.13) compared to the control (37.67) over the two years (Table 4). This result revealed that the combined application rhizobium and NPSB could be the optimum levels to obtain the higher number of pods per plant.

Table 3. Chickpea Yield and Yield Components as influenced by inoculation and NPSB application in Laelay maichew (Hatsebo), 2017

\begin{tabular}{cccccc}
\hline Ino*NPSB $\left(\mathrm{kg} \mathrm{ha}{ }^{-1}\right)$ & DTM & PH $(\mathrm{cm})$ & NPPL & GY $\left(\mathrm{kg} \mathrm{ha}^{-1}\right)$ & HSW $(\mathrm{g})$ \\
\hline $0 * 0$ & $112.67 \mathrm{a}$ & $32 \mathrm{e}$ & $37.67 \mathrm{~d}$ & $1357.3 \mathrm{f}$ & $24.97 \mathrm{~b}$ \\
$0 * 25$ & $113.33 \mathrm{a}$ & $33.4 \mathrm{de}$ & $44.27 \mathrm{~cd}$ & $1483.2 \mathrm{ef}$ & $25.4 \mathrm{ab}$ \\
$0 * 50$ & $114 \mathrm{ab}$ & $34.33 \mathrm{cde}$ & $45.9 \mathrm{bcd}$ & $1851.7 \mathrm{~d}$ & $25.37 \mathrm{ab}$ \\
$0 * 75$ & $115 \mathrm{ab}$ & $34.87 \mathrm{cde}$ & $47.8 \mathrm{bcd}$ & $1937.6 \mathrm{~d}$ & $25.5 \mathrm{ab}$ \\
$0 * 100$ & $114.67 \mathrm{abc}$ & $34.27 \mathrm{cde}$ & $46.6 \mathrm{bcd}$ & $2013.9 \mathrm{~d}$ & $25.7 \mathrm{ab}$ \\
$0^{*} 125$ & $113.67 \mathrm{bc}$ & $37.2 \mathrm{abc}$ & $55.33 \mathrm{abc}$ & $2029 \mathrm{~d}$ & $25.3 \mathrm{ab}$ \\
$0^{*} 150$ & $115 \mathrm{bcd}$ & $36.8 \mathrm{abc}$ & $53.33 \mathrm{abc}$ & $2711.7 \mathrm{c}$ & $25.17 \mathrm{~b}$ \\
$1 * 0$ & $114 \mathrm{bcd}$ & $34.47 \mathrm{cde}$ & $46.2 \mathrm{bcd}$ & $1451.1 \mathrm{ef}$ & $25.13 \mathrm{~b}$ \\
$1 * 25$ & $114 \mathrm{bcd}$ & $36 \mathrm{bcd}$ & $51.93 \mathrm{bc}$ & $1729.4 \mathrm{de}$ & $25.47 \mathrm{ab}$ \\
$1 * 50$ & $115 \mathrm{bcd}$ & $35.27 \mathrm{~cd}$ & $52.73 \mathrm{abc}$ & $2980.7 \mathrm{bc}$ & $25.83 \mathrm{ab}$ \\
$1 * 75$ & $114 \mathrm{~cd}$ & $36.47 \mathrm{bcd}$ & $56.3 \mathrm{abc}$ & $3151.6 \mathrm{ab}$ & $26.46 \mathrm{a}$ \\
$1 * 100$ & $115.67 \mathrm{bcd}$ & $38.4 \mathrm{ab}$ & $57.9 \mathrm{ab}$ & $3332.2 \mathrm{a}$ & $26.03 \mathrm{ab}$ \\
$1 * 125$ & $116.33 \mathrm{bcd}$ & $38.6 \mathrm{ab}$ & $65.13 \mathrm{a}$ & $3401.9 \mathrm{a}$ & $25.77 \mathrm{ab}$
\end{tabular}




\begin{tabular}{cccccc}
$1 * 150$ & $117.67 \mathrm{bcd}$ & $39.8 \mathrm{a}$ & $57.2 \mathrm{abc}$ & $3433.1 \mathrm{a}$ & $25.97 \mathrm{ab}$ \\
\hline Grand.mean & 114.64 & 35.84 & 51.31 & 2347.46 & 25.57 \\
LSD $(5 \%)$ & 2.62 & 3.08 & 13.19 & 308.07 & 1.18 \\
CV $(\%)$ & 1.36 & 5.14 & 15.37 & 7.84 & 2.75 \\
\hline
\end{tabular}

Ino indicates for Rhzobium inoculantion; $0=$ uninoculated, $1=$ inoculated with rhizobium; $\mathrm{DM}=$ days to maturity; $\mathrm{PH}=$ plant height; $\mathrm{NPPL}=$ number of pods per plant; $\mathrm{GY}=$ grain yield; $\mathrm{HSW}=$ hundred seed weight. Means followed by the same letter(s) with in a column are not significantly different at $\mathrm{P} \leq 0.05$

In relation to grain yield analysis of variance revealed that statistical significant difference $(\mathrm{P}<0.05)$ among the combined application of rhizobium and NPSB. Application of NPSB and rhizobium inoculants at the same time had synergistic effect on the yield of chickpea thus increased the yield. All the treatments gave higher number of pods per plant over the control. Application of $125 \mathrm{~kg} / \mathrm{ha} \mathrm{NPSB}$ along with rhizobium inoculation had resulted $134 \%$ yield inncrea than the untreated check (control). Synergetic and positive response of rhizobium inoculation and di-amonium phsphate was reported in Birhanu and Pant (2012) in chickpea grain yield at shoa robit area.

Hundred seed weight (HSW) analysis of variance test showed a significant statistical difference ( $\mathrm{P} \leq 0.05)$ among the combination of rhizobium inoculation and NPSB application (Table 4). The highest hundred seed weight $(26.46 \mathrm{~g})$ was recorded with inoculation rhizobium inoculants along with $75 \mathrm{~kg} \mathrm{NPSB} \mathrm{ha}^{-1}$, followed by rhizobium inoculation along with $100 \mathrm{~kg}$ NPSB ha-1 $^{-1}$ which were significantly higher than control.

Table 4. Combined mean value of Chickpea Yield and Yield components as influenced by the application of Rhizobium inoculation and NPSB in Laelay maichew (Hatsebo) 2016-2017

\begin{tabular}{cccccc}
\hline Ino*NPSB $\left(\mathrm{kg} \mathrm{ha}^{-1}\right)$ & $90 \%$ DTM & PH $(\mathrm{cm})$ & NPPL & GY $\left(\mathrm{kg} \mathrm{ha}^{-1}\right)$ & HSW $(\mathrm{g})$ \\
\hline $0 * 0$ & 108.33 & $32.9 \mathrm{f}$ & $43.5 \mathrm{f}$ & $1501 \mathrm{e}$ & $24.98 \mathrm{e}$ \\
$0 * 25$ & 109.67 & $34.67 \mathrm{ef}$ & $49.73 \mathrm{ef}$ & $1631.5 \mathrm{de}$ & $25.45 \mathrm{cde}$ \\
$0 * 50$ & 109.83 & $35.43 \mathrm{cde}$ & $49.70 \mathrm{c}-\mathrm{f}$ & $1903.7 \mathrm{cde}$ & $25.25 \mathrm{de}$ \\
$0 * 75$ & 110 & $36.03 \mathrm{ed}$ & $56.63 \mathrm{c}-\mathrm{f}$ & $1956.7 \mathrm{~cd}$ & $25.6 \mathrm{bcde}$ \\
$0 * 100$ & 110.67 & $35.62 \mathrm{de}$ & $59.97 \mathrm{~b}-\mathrm{e}$ & $2191.8 \mathrm{bc}$ & $26.28 \mathrm{abc}$ \\
$0 * 125$ & 110 & $37.73 \mathrm{bc}$ & $66.47 \mathrm{a}-\mathrm{e}$ & $2261.3 \mathrm{bc}$ & $26.18 \mathrm{a}-\mathrm{d}$ \\
$0 * 150$ & 111.17 & $37.33 \mathrm{bcd}$ & $64.27 \mathrm{def}$ & $2616.9 \mathrm{e}$ & $25.95 \mathrm{a}-\mathrm{d}$ \\
$1 * 0$ & 109.5 & $34.47 \mathrm{ef}$ & $51.95 \mathrm{def}$ & $1517.6 \mathrm{e}$ & $25.47 \mathrm{cde}$ \\
$1 * 25$ & 109.5 & $36 \mathrm{cde}$ & $57.77 \mathrm{c}-\mathrm{f}$ & $1640.4 \mathrm{de}$ & $25.43 \mathrm{cde}$ \\
$1 * 50$ & 110.17 & $36.17 \mathrm{cde}$ & $58.73 \mathrm{~b}-\mathrm{f}$ & $1910.7 \mathrm{cde}$ & $26.18 \mathrm{a}-\mathrm{d}$ \\
$1 * 75$ & 110.33 & $37.1 \mathrm{bcd}$ & $65.95 \mathrm{a}-\mathrm{d}$ & $2200.7 \mathrm{c}$ & $26.53 \mathrm{ab}$ \\
$1 * 100$ & 111.67 & $38.57 \mathrm{ab}$ & $70.18 \mathrm{abc}$ & $2489.9 \mathrm{~b}$ & $26.65 \mathrm{a}$ \\
$1 * 125$ & 111.83 & $38.83 \mathrm{ab}$ & $76.8 \mathrm{a}$ & $3514.3 \mathrm{a}$ & $26.57 \mathrm{a}$ \\
$1 * 150$ & 113 & $40.40 \mathrm{a}$ & $73.83 \mathrm{ab}$ & $3609.1 \mathrm{a}$ & $26.82 \mathrm{a}$ \\
\hline Grand.mean & 110.4 & 36.53 & 60.39 & 2210.39 & 25.95 \\
LSD $(5 \%)$ & $\mathrm{NS}$ & 2.11 & 15.31 & 437.94 & 0.94 \\
CV $(\%)$ & 4.4 & 5.01 & 22.2 & 17.21 & 3.16 \\
\hline
\end{tabular}

Ino indicates for Rhzobium inoculantion; $0=$ uninoculated, $1=$ inoculated with rhizobium; $\mathrm{DM}=$ days to maturity; $\mathrm{PH}=$ plant height; $\mathrm{NPPL}=$ number of pods per plant; $\mathrm{GY}=$ grain yield; $\mathrm{HSW}=$ hundred seed weight. Means followed by the same letter(s) with in a column are not significantly different at $\mathrm{P}=0.05$ 
Table 5. Net benefit analysis of NPSB application and rhizobium inoculation on chickpea grain yield in Hatsebo (2016-2017)

\begin{tabular}{cccccc}
\hline Ino*NPSB $\left(\mathrm{kg} \mathrm{ha}^{-1}\right)$ & $\begin{array}{c}\text { Yield } \\
\left(\mathrm{kg} \mathrm{ha}^{-1}\right)\end{array}$ & adj yield & $\begin{array}{c}\text { Gross field } \\
\text { benefit }\end{array}$ & Total variable cost & Net benefit \\
\hline $0 * 0$ & 1501 & 1350.9 & 29719.8 & 0 & 29719.8 \\
$1 * 0$ & 1517.6 & 1365.84 & 30048.48 & 40 & 30008.48 \\
$0 * 25$ & 1631.5 & 1468.35 & 32303.7 & 482.19 & 31821.5125 \\
$1 * 25$ & 1640.4 & 1476.36 & 32479.92 & 522.19 & 31957.7325 \\
$0 * 50$ & 1903.7 & 1713.33 & 37693.26 & 964.38 & 36728.885 \\
$0 * 50$ & 1910.7 & 1719.63 & 37831.86 & 1004.38 & 36827.485 \\
$0 * 75$ & 1956.7 & 1761.03 & 38742.66 & 1446.56 & 37296.0975 \\
$1 * 75$ & 2200.7 & 1980.63 & 43573.86 & 1486.56 & 42087.2975 \\
$0 * 100$ & 2191.8 & 1972.62 & 43397.64 & 1928.75 & $41468.89 \mathrm{D}$ \\
$1 * 100$ & 2489.9 & 2240.91 & 49300.02 & 1968.75 & 47331.27 \\
$0 * 125$ & 2261.3 & 2035.17 & 44773.74 & 2410.94 & 42362.8025 \\
$1 * 125$ & 3514.3 & 3162.87 & 69583.14 & 2450.94 & 67132.2025 \\
$0 * 150$ & 2616.9 & 2355.21 & 51814.62 & 2893.13 & $48921.495 \mathrm{D}$ \\
$1 * 150$ & 3609.1 & 3248.19 & 71460.18 & 2933.13 & 68527.055 \\
\hline
\end{tabular}

$0=$ inoculated; $1=$ inoculated; $\mathrm{D}=$ Dominated (any treatment that has net benefit less than or equal to that of a treatment with lower cost that vary is dominated)

Partial budget analysis of combine effects of rhizobium inoculation and NPSB fertilizer applied indicated that inoculation with $125 \mathrm{~kg} \mathrm{NPSB} \mathrm{ha}^{-1}$ was the most economical with maximum marginal rate of return (4106.48\%) followed by inoculation along with 75 and $100 \mathrm{~kg} \mathrm{ha}^{-1}$ NPSB respectively (Table $5 \&$ Table 6).

Table 6. Mariginal rate of analysis of NPSB application and rhizobium inoculation on chickpea grain yield in Hatsebo (2016-2017)

\begin{tabular}{cccccc}
\hline Ino*NPSB $\left(\mathrm{kg} \mathrm{ha}^{-1}\right)$ & Adjusted yield & Gross field benefit & Total variable cost & Net benefit & MRR\% \\
\hline $0 * 0$ & 1350.9 & 29719.8 & 0 & 29719.8 & - \\
$1 * 0$ & 1365.84 & 30048.48 & 40 & 30008.48 & 721.7 \\
$0 * 25$ & 1468.35 & 32303.7 & 482.19 & 31821.5125 & 410.01 \\
$1 * 25$ & 1476.36 & 32479.92 & 522.19 & 31957.7325 & 340.55 \\
$0 * 50$ & 1713.33 & 37693.26 & 964.38 & 36728.885 & 1078.99 \\
$1 * 50$ & 1719.63 & 37831.86 & 1004.38 & 36827.485 & 246.5 \\
$1 * 75$ & 1980.63 & 43573.86 & 1486.56 & 42087.2975 & 1090.82 \\
$1 * 100$ & 2240.91 & 49300.02 & 1968.75 & 47331.27 & 1087.54 \\
$1 * 125$ & 3162.87 & 69583.14 & 2450.94 & 67132.2025 & 4106.48 \\
$1 * 150$ & 3248.19 & 71460.18 & 2933.13 & 68527.055 & 289.28 \\
\hline
\end{tabular}

$0=$ inoculated; $1=$ inoculated; Marginal rate of return = Marginal net benefit $\mathrm{x}$ 100/Marginal cost; Current Price of chickpea $=22 \mathrm{birr} / \mathrm{kg}$

\section{Conclusion}

The interaction effect of NPSB and inoculation for most of the parameters were significant in each year and across the two years. The highest grain yield of chickpea was recorded from the inoculated seed planted with the application of 125,150 and $100 \mathrm{~kg} \mathrm{ha}^{-1}$ blended (NPSB) fertilizers, respectively in decreasing order over the two 
years at Hatsebo research site in Laelay maichew district. However maximum marginal rate of return were obtained from 125, 75 and $100 \mathrm{~kg} \mathrm{ha}^{-1}$ NPSB along with rhizobiaum inoculation. Therefore, $125 \mathrm{~kg} \mathrm{ha}^{-1} \mathrm{NPSB}$ along with rhizobiaum inoculation would be the optimum treatment combination for enhancing chickpea grain yield and profitability in soils having low NPSB availability.

\section{Conflict of interest}

The authors have not declared any conflict of interest.

\section{Acknowledgements}

The authors would like to thank Tigrai Agricultural Research Institue for the financial support of the research study and great appreciation goes to crop core process colleagues for supporting during implementation of the study.

\section{References}

Abdula, I. A. (2013). Agronomic and symbiotic characteristics of chickpea. In Cicer arietinum (L.), as influenced by Rhizobium inoculation and phosphorus fertilization under farming systems of Wolaita area, Ethiopia. M.Sc. Thesis, Wageningen University.

CIMMYT (1988). From agronomic data to farmer recommendations: an economics work book. The International Maize and Wheat Improvement Center, Mexico, pp. 1-63.

Ethiopian Agricultural Transformation Agency (ATA) and Ministry of Agriculture (2014). Soil fertility status and fertilizer recommendation atlas for Tigray regional state, Addis Ababa, Ethiopia.

Gil, J., Nadal, S., Luna, D., Moreno, M. T., \& de Haro, A. (1996). Variability of some physico-chemical characters in Desi and Kabuli chickpea types. Journal of Food Science Agriculture, (71), 179-184. https://doi.org/10.1002/(SICI)1097-0010(199606)71:2<179::AID-JSFA566>3.0.CO;2-7

Herrera E. (2005). Soil Test Interpretations Guide A-122". College of Agriculture and Home Economics, New Mexico State University.

Ibrikci, H., Knewtson, S., \& Grusak, M. A. (2003). Chickpea leaves as a vegetable green for humans: Evaluation of mineral composition. Journal of Science Food Agriculture, (83), 945-950. https://doi.org/10.1002/jsfa.1427

Messele, B., \& Pant, L. M. (2012). Effects of Inoculation of Sinorhizobium ciceri and Phosphate Solubilizing Bacteria on Nodulation, Yield and Nitrogen and Phosphorus Uptake of Chickpea (Cicer arietinum L.) in Shoa Robit Area. Journal of Biofertilizer and Bio pesticides, 3(5), 1-6. https://doi.org/10.4172/21556202.10000129

Millan, T. J., Clarke, H. J., Kadambot, H., Siddique, H. K. M., Gaur, P. M., Kumar, J., Gill, J., Kahl, G., \& Winter, P. (2006). Chickpea molecular breeding: New tools and concepts. Euphytica, (147), 81-103. https://doi.org/10.1007/s10681-006-4261-4

Pande, S., Sharma, M., Gaur, P. M., Tripathi, S., Kaur, L., Basandrai, A., Khan, T., Gowda, C. L. L., \& Siddique K. H. M. (2011). Development of screening techniques and identification of new sources of resistance to Ascochyta blight disease of chickpea. Australasian Plant Pathology, (40), 149-156. https://doi.org/10.1007/s13313-010-0024-8

Petersen, R. G. (1994). Agricultural Field Experiments Design and Analysis. Marcel Dekker, Inc., New York. https://doi.org/10.1201/9781482277371

Statistical Analysis System. (2002). Version 9.1.SAS Institute Inc., Cary, NC, USA.

\section{Copyrights}

Copyright for this article is retained by the author(s), with first publication rights granted to the journal.

This is an open-access article distributed under the terms and conditions of the Creative Commons Attribution license (http://creativecommons.org/licenses/by/4.0/). 